\title{
Trypanocidal and leishmanicidal activity of six limonoids
}

\author{
Dietmar Steverding ${ }^{1} \cdot$ Lazare S. Sidjui ${ }^{2,3} \cdot$ Éden Ramalho Ferreira ${ }^{4,5} \cdot$ Bathelemy Ngameni $^{6} \cdot$ Gabriel N. Folefoc $^{3}$. \\ Valérie Mahiou-Leddet ${ }^{7} \cdot$ Evelyne Ollivier $^{7} \cdot$ G. Richard Stephenson ${ }^{8} \cdot$ Thomas E. Storr $^{8} \cdot$ Kevin M. Tyler $^{4}$
}

Received: 3 February 2020 / Accepted: 31 March 2020 / Published online: 10 April 2020

(c) The Author(s) 2020

\begin{abstract}
Six limonoids [kotschyienone A and B (1, 2), 7-deacetylgedunin (3), 7-deacetyl-7-oxogedunin (4), andirobin (5) and methyl angolensate (6)] were investigated for their trypanocidal and leishmanicidal activities using bloodstream forms of Trypanosoma brucei and promastigotes of Leishmania major. Whereas all compounds showed anti-trypanosomal activity, only compounds 1-4 displayed anti-leishmanial activity. The 50\% growth inhibition $\left(\mathrm{GI}_{50}\right)$ values for the trypanocidal and leishmanicidal activity of the compounds ranged between 2.5 and $14.9 \mu \mathrm{M}$. Kotschyienone A (1) was found to be the most active compound with a minimal inhibition concentration (MIC) value of $10 \mu \mathrm{M}$ and $\mathrm{GI}_{50}$ values between 2.5 and $2.9 \mu \mathrm{M}$. Only compounds 1 and $\mathbf{3}$ showed moderate cytotoxicity against HL-60 cells with MIC and GI $_{50}$ values of $100 \mu \mathrm{M}$ and $31.5-46.2 \mu \mathrm{M}$, respectively. Compound 1 was also found to show activity against intracellular amastigotes of $L$. major with $\mathrm{a} \mathrm{GI}_{50}$ value of $1.5 \mu \mathrm{M}$. The results suggest that limonoids have potential as drug candidates for the development of new treatments against trypanosomiasis and leishmaniasis.
\end{abstract}

Keywords Limonoids $\cdot$ African trypanosomiasis $\cdot$ Trypanosoma brucei $\cdot$ Leishmaniasis $\cdot$ Leishmania major

\section{Introduction}

Trypanosomiasis and leishmaniasis are devastating diseases for both humans and their domestic animals. Trypanosome parasites cause sleeping sickness in humans and nagana disease in cattle in Africa and Chagas disease in humans in Latin America [1,2]. The different Leishmania parasites cause a variety of clinical conditions (localised skin lesions,

Electronic supplementary material The online version of this article (https://doi.org/10.1007/s11418-020-01408-7) contains supplementary material, which is available to authorized users.

Dietmar Steverding

dsteverding@hotmail.com

$\triangle$ Bathelemy Ngameni

bath_ngameni@yahoo.fr

1 Bob Champion Research and Education Building, Norwich Medical School, University of East Anglia, Norwich NR4 7UQ, UK

2 Institute of Medical Research and Medicinal Plant Studies, P.O. Box 13033, Yaoundé, Cameroon

3 Bioorganic and Medicinal Chemistry Laboratory, Department of Organic Chemistry, Faculty of Sciences, University of Yaoundé I, Yaoundé, Cameroon mucosal ulcers, and internal organ damage) in humans worldwide [3]. These parasites are kinetoplastid protozoans and are transmitted to their mammalian host by insect vectors. Treatment of these parasitoses relies on chemotherapy but only a few drugs are available. However, most of the drugs are not well tolerated or show toxic side effects, are not very effective, and are being increasingly subject to drug resistance. Therefore, effective and better-tolerated chemotherapies are urgently needed for the treatment of trypanosomiasis and leishmaniasis.

4 BioMedical Research Centre, Norwich Medical School, University of East Anglia, Norwich NR4 7TJ, UK

5 Departamento de Microbiologia, Imunologia e Parasitologia, Escola Paulista de Medicina, Universidade Federal de São Paulo, São Paulo, Brazil

6 Department of Pharmacognosy and Pharmaceutical Chemistry, Faculty of Medicine and Biomedical Science, University of Yaoundé I, Yaoundé, Cameroon

7 Aix-Marseille University, Avignon University, CNRS, IRD, IMBE, FAC PHARM, Marseille, France

8 School of Chemistry, University of East Anglia, Norwich NR4 7TJ, UK 
Many approved drugs are based on natural compounds and their derivatives [4]. In addition, a considerable number of natural products have been shown to display potent anti-trypanosomal and anti-leishmanial activity [5]. Plants that are used in traditional medicine are promising starting materials for the discovery of natural compounds with trypanocidal and leishmanicidal activity. One such plant is Pseudocedrela kotschyi (Schweinf.) Harms (Meliaceae), which is used for the treatment of trypanosomiasis in the Kaduna state of Nigeria [6]. Furthermore, dichloromethane extracts of the roots of $P$. kotschyi have been shown to display anti-leishmanial activity against intracellular amastigotes of L. major [7].

In this study, we investigated the trypanocidal and leishmanicidal activity of six limonoids (Fig. 1, compounds 1-6) isolated from the roots of $P$. kotschyi.

Fig. 1 Structures of compounds

1-6. Kotschyienone A (1),

kotschyienone B (2), 7-deacetylgedunin (3), 7-deacetyl7-oxogedunin (4), andirobin (5), methyl angolensate (6)

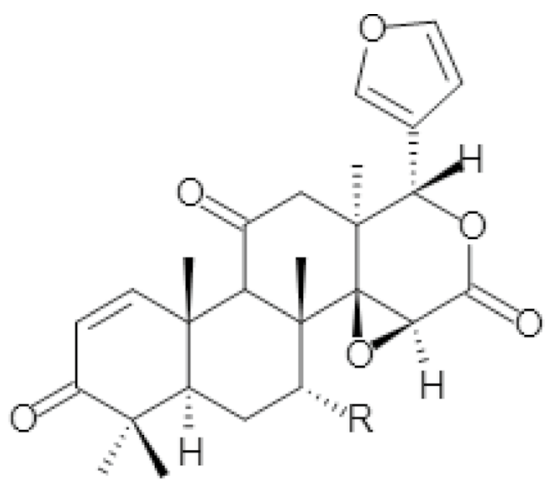

$$
1 \mathrm{R}=\mathrm{H}
$$

$2 \mathrm{R}=\mathrm{OH}$

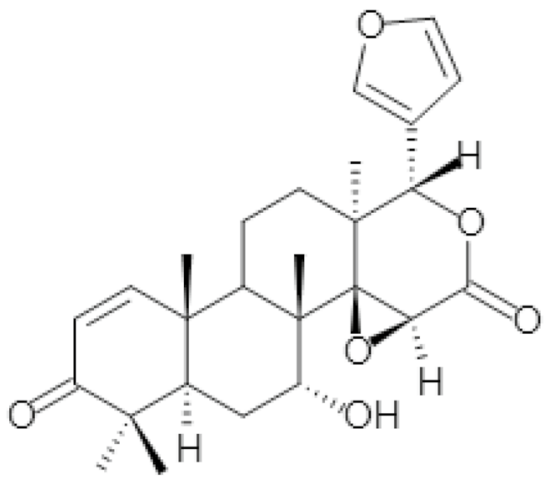

3<smiles>C=C1[C@H]([C@@]2(C)C=CC(=O)C(C)(C)C2CC(=O)OC)CC[C@]2(C)[C@@H](c3ccoc3)OC(=O)[C@H]3O[C@]132</smiles>

5<smiles>CC1(C)C(=O)C=C[C@]2(C)C3CC[C@@]4(C)[C@@H](c5ccoc5)OC(=O)[C@H]5O[C@]54[C@@]3(C)C(=O)C[C@]12C</smiles>

4

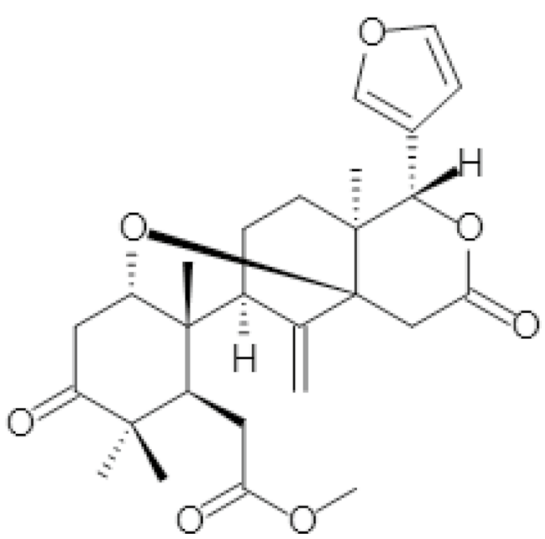

6 


\section{Experimental}

\section{Compounds}

The limonoids 1-6 were isolated from the roots of $P$. kotschyi as previously described [8]. The compounds have been characterized by NMR (kotschyienone A and B (1, 2 [8], 7-deacetylgedunin (3) [9, 10], 7-deacetyl-7-oxogedunin (4) [9, 11], andirobin (5) [12] and methyl angolensate (6) [11]) and their purity was judged to be about $95 \%$ by TLC. The ${ }^{1} \mathrm{H}-\mathrm{NMR}$ and ${ }^{13} \mathrm{C}$-NMR spectra of 1-6 are shown in Supplementary Figures S1-6.

\section{Cell culture}

Bloodstream forms of Trypanosoma brucei (clone 427-221a [13]) and human myeloid leukaemia HL-60 cells [14] were maintained in Baltz medium [15] supplemented with 16.7\% heat-inactivated bovine serum in a humidified atmosphere containing $5 \% \mathrm{CO}_{2}$ at $37^{\circ} \mathrm{C}$. Promastigotes of Leishmania major (strain MHOM/IL/81/Friedlin [16]) were cultured in Schneider's insect medium supplemented with $10 \%$ heat-inactivated foetal bovine serum in a humidified atmosphere containing $5 \% \mathrm{CO}_{2}$ at $27{ }^{\circ} \mathrm{C}$.

\section{In vitro toxicity assay}

Toxicity assays were carried out as previously described with some modifications $[17,18]$. In brief, cells were seeded in 96-well plates in a final volume of $200 \mu \mathrm{L}$ of appropriate medium containing various concentrations of test compounds (tenfold dilution from $100 \mu \mathrm{M}$ to $1 \mathrm{nM}$ ) and $1 \%$ DMSO. Wells just containing medium and $1 \%$ DMSO served as controls. The initial cell densities were $1 \times 10^{4} / \mathrm{mL}$ for $T$. brucei bloodstream forms, $2.5 \times 10^{5} / \mathrm{mL}$ for $L$. major promastigotes, and $5 \times 10^{4} / \mathrm{mL}$ for HL- 60 cells. After $24 \mathrm{~h}$ incubation, $20 \mu \mathrm{L}$ of a $0.5 \mathrm{mM}$ resazurin solution prepared in PBS was added and the cells were incubated for a further $48 \mathrm{~h}$. Thereafter, the absorbance of wells was read on a BioTek ELx808 microplate reader using a test wavelength of $570 \mathrm{~nm}$ and a reference wavelength of $630 \mathrm{~nm}$. The $50 \%$ growth inhibition $\left(\mathrm{GI}_{50}\right)$ value, i.e., the concentration of a compound necessary to reduce the growth rate of cells by $50 \%$ compared to the control, was determined by linear interpolation [19]. The minimum inhibitory concentration (MIC) values, i.e. the concentration of a compound at which all trypanosomes and human cells were killed, was determined microscopically.

\section{Intra-macrophages amastigote assay}

The intra-macrophages amastigote assay was performed as previously described with some modification [20]. In brief,
$1 \mathrm{~mL}$ of $\mathrm{J} 774$ cells $\left(7 \times 10^{4}\right)$ suspended in RPMI supplemented with $10 \%$ foetal bovine serum were pipetted into wells of a 24 well plate containing sterile glass coverslips. Subsequently, cells were incubated overnight at $37{ }^{\circ} \mathrm{C}$ and $5 \% \mathrm{CO}_{2}$ in a humidified incubator. The next day, metacyclic $L$. major promastigotes (MOI 20:1) were added and the plates incubated for $24 \mathrm{~h}$ at $34{ }^{\circ} \mathrm{C}$ and $5 \% \mathrm{CO}_{2}$ in a humidified incubator. After $24 \mathrm{~h}$ incubation, cells were washed 4 times with PBS to remove parasites that had not invaded any macrophage. Then, cells were incubated with compound 1 at the following concentrations: 10, 2.5, 1.25, 0.625 and $0.1 \mu \mathrm{M}$. Amphotericin B $(0.1 \mu \mathrm{M})$ was used as a positive control and no drug treatment as a negative control. After $72 \mathrm{~h}$ of drug incubation, cells were gently washed 4 times with PBS and fixed with $4 \%$ paraformaldehyde for $30 \mathrm{~min}$. Thereafter, cells were washed once with water and stained with Giemsa for $40 \mathrm{~min}$. Cells on coverslips were then destained using the acetone-xylene protocol as follows: first, pure acetone; second, pure acetone; third, acetone/ xylene 9:1; forth, acetone/xylene 7:3; fifth, acetone/xylene $3: 7$; sixth, pure xylene. Finally, coverslips were mounted on slides with Entellan new mounting medium. Infection index (parasites/cell) were determined by counting approximately 300 cells per coverslips using an Olympus BX50 microscope with a $100 \times$ N.A. 1.35 oil immersion objective.

\section{Results and discussion}

All six limonoids 1-6 showed a dose-dependent inhibitory effect on the growth of bloodstream forms of T. brucei with MIC values ranging from 10 to $>100 \mu \mathrm{M}$ and $\mathrm{GI}_{50}$ values ranging from 2.48 to $14.5 \mu \mathrm{M}$ (Table 1). Similar activities were also observed with promastigotes of $L$. major for the four gedunin-type limonoids 1-4 (Table 1). In contrast to their trypanocidal activity, the two andirobin-type limonoids 5 and $\mathbf{6}$ displayed no leishmanicidal activity (MIC and $\mathrm{GI}_{50}>100 \mu \mathrm{M}$, Table 1). The most active compound against both parasites was 1 with a MIC value of $10 \mu \mathrm{M}$ and $\mathrm{GI}_{50}$ value of $2-3 \mu \mathrm{M}$ (Table 1). On the other hand, only compounds $\mathbf{1}$ and $\mathbf{3}$ showed some cytotoxic activity against human HL-60 cells with MIC values of $100 \mu \mathrm{M}$ and $\mathrm{GI}_{50}$ values in the mid micromolar range (Table 1). The other four compounds $(\mathbf{2}, \mathbf{4}, \mathbf{5}$ and $\mathbf{6})$ displayed no cytotoxicity against HL-60 cells (MIC and $\mathrm{GI}_{50}>100 \mu \mathrm{M}$, Table 1). Based on the antiparasitic and cytotoxic activities, only the gedunintype limonoid 1 exhibited moderated selectivity indices with MIC and $\mathrm{GI}_{50}$ ratios of $\geq 10$ (Table 2).

Compared with suramin and amphotericin B, two drugs used in the treatment of sleeping sickness and cutaneous leishmaniasis, respectively, the six limonoids were 10-1000 times less active (Table 1). The higher antiparasitic activity 
Table 1 In vitro trypanocidal, leishmanicidal and cytotoxic activity of the limonoids 1-6

\begin{tabular}{|c|c|c|c|c|c|c|}
\hline \multirow[t]{2}{*}{ Compound } & \multicolumn{2}{|l|}{ T. brucei } & \multicolumn{2}{|l|}{ L. major } & \multicolumn{2}{|l|}{ HL-60 cells } \\
\hline & $\operatorname{MIC}(\mu \mathrm{M})$ & $\mathrm{GI}_{50}(\mu \mathrm{M})$ & $\operatorname{MIC}(\mu \mathrm{M})$ & $\mathrm{GI}_{50}(\mu \mathrm{M})$ & $\mathrm{MIC}(\mu \mathrm{M})$ & $\mathrm{GI}_{50}(\mu \mathrm{M})$ \\
\hline 1 & 10 & $2.48 \pm 0.12$ & 10 & $2.86 \pm 0.89$ & 100 & $31.5 \pm 3.7$ \\
\hline 2 & 100 & $14.2 \pm 2.9$ & 100 & $14.9 \pm 5.9$ & $>100$ & $>100$ \\
\hline 3 & 100 & $14.5 \pm 3.2$ & 100 & $11.6 \pm 1.6$ & 100 & $46.2 \pm 6.7$ \\
\hline 4 & $>100$ & $3.18 \pm 0.48$ & $>100$ & $7.63 \pm 2.78$ & $>100$ & $>100$ \\
\hline 5 & $>100$ & $11.5 \pm 6.3$ & $>100$ & $>100$ & $>100$ & $>100$ \\
\hline 6 & $>100$ & $6.04 \pm 2.25$ & $>100$ & $>100$ & $>100$ & $>100$ \\
\hline Suramin & 1 & $0.042 \pm 0.004$ & nt & $\mathrm{nt}$ & $>100$ & $>100$ \\
\hline Amphotericin B & nt & $\mathrm{nt}$ & 0.1 & $0.036 \pm 0.001$ & $>100$ & $50.7 \pm 9.3$ \\
\hline
\end{tabular}

$n t$ not tested

Table 2 Selectivity indices of the limonoids 1-6

\begin{tabular}{llllll}
\hline Compound & \multicolumn{2}{l}{ T. brucei } & & \multicolumn{2}{l}{ L. major } \\
\cline { 2 - 3 } & MIC ratio & $\mathrm{GI}_{50}$ ratio & & MIC ratio & $\mathrm{GI}_{50}$ ratio \\
\hline $\mathbf{1}$ & 10 & 12.7 & 10 & 11.0 \\
$\mathbf{2}$ & $>1$ & $>7.2$ & $>1$ & $>6.7$ \\
$\mathbf{3}$ & 1 & 3.2 & 1 & 4.0 \\
$\mathbf{4}$ & 1 & $>31.4$ & 1 & $>13.1$ \\
$\mathbf{5}$ & 1 & $>8.7$ & 1 & 1 \\
$\mathbf{6}$ & 1 & $>16.6$ & 1 & 1 \\
Suramin & $>100$ & $>2381$ & & nd & $\mathrm{nd}$ \\
Amphotericin B & nd & nd & $>1000$ & 1408 \\
\hline
\end{tabular}

MIC ratio $\mathrm{MIC}_{\mathrm{HL}-60} / \mathrm{MIC}_{\text {parasite }}, G_{50}$ ratio $\mathrm{GI}_{50, \mathrm{HL}-60} / \mathrm{GI}_{50 \text {,parasite, }} \mathrm{MIC}$ ratios and $\mathrm{GI}_{50}$ ratios were calculated from $\mathrm{MIC}$ and $\mathrm{GI}_{50}$ values shown in Table 1

nd not determined

of the drugs is also reflected in their greater selectivity indices of at least $>100$ (Table 2).

As compound 1 was found to be the most potent leishmanicidal limonoid, we investigated its ability to kill $L$. major amastigotes within macrophages. The compound was able to reduce the parasite burden of infected macrophages with an $\mathrm{ED}_{50}$ (50\% effective dose) of $1.51 \mu \mathrm{M}$ (Fig. 2). Thus, compound $\mathbf{1}$ was almost twice as effective in affecting intracellular amastigotes than extracellular promastigotes $\left(\mathrm{GI}_{50 \text { (promastigotes) }}=2.86 \mu \mathrm{M}\right.$ vs ED $\left.\mathrm{ED}_{50 \text { (amastigotes) }}=1.51 \mu \mathrm{M}\right)$. At $10 \mu \mathrm{M}$, compound 1 killed completely intracellular amastigotes and only vacuoles containing fragments of parasites could be seen (Supplementary Figure S7). However, compared with amphotericin B, compound $\mathbf{1}$ was less potent in killing amastigotes within macrophages. The licensed drug was able to completely destroy intracellular amastigotes at a concentration of $0.1 \mu \mathrm{M}$ (Fig. 2).

The trypanocidal and leishmanicidal activity of compounds 1-6 are in good agreement with previously reported antiprotozoal activities. For instance, the $\mathrm{GI}_{50}$ values for their anti-plasmodial activity were found to be within the

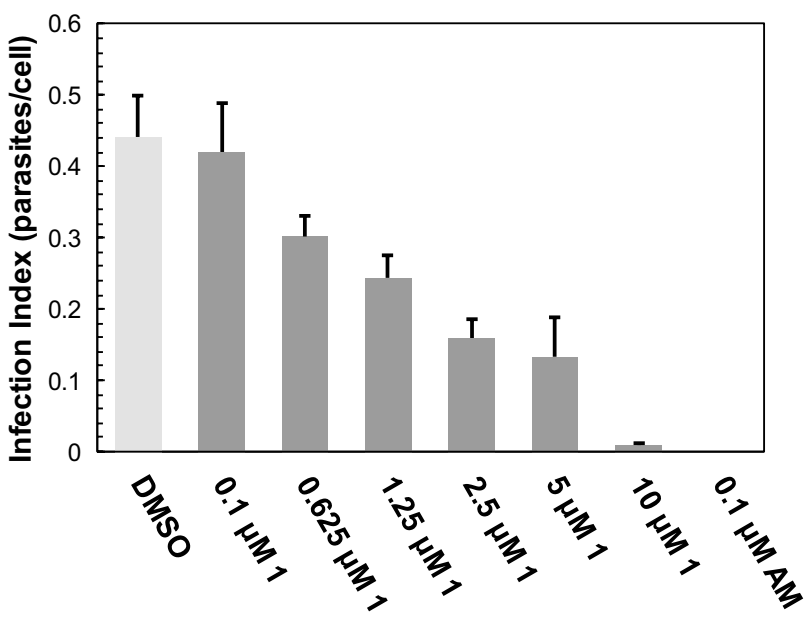

Fig. 2 Effect of compound $\mathbf{1}$ on intracellular L. major amastigotes. After infection of $\mathbf{J} 774$ macrophages with metacyclic promastigotes of $L$. major, cells were treated with compound $\mathbf{1}$ or amphotericin B (AM) or with DMSO alone (DMSO) $24 \mathrm{~h}$ post infection. After $72 \mathrm{~h}$ incubation, coverslips with cells were washed with PBS, fixed with paraformaldehyde and stained with Giemsa. Subsequently, cells were destained and coverslips mounted, and the infection index determined. Mean values $\pm S D$ of three independent experiments run in triplicate are shown

range of 1.7-19.3 $\mu \mathrm{M}$ [8]. Compounds 3 and $\mathbf{4}$ have been previously reported to inhibit the growth of bloodstream forms of T. brucei rhodesiense with $\mathrm{GI}_{50}$ values of $3.4 \mu \mathrm{M}$ [21]. Axenic grown amastigotes of L. donovani were affected by 3 and 4 with $\mathrm{GI}_{50}$ values of around $1 \mu \mathrm{M}$ [21]. These activities are somewhat lower than those we found for $\mathbf{3}$ and 4 with promastigotes of $L$. major. The observed differences may be due to that axenic grown amastigotes are more sensitive as they are removed from their natural environment of a host cell.

Structure-activity relationship analysis revealed that the presence of a hydroxyl group at the C-7 position reduces the activity of the gedunin-type limonoids. For example, compound 2 with a hydroxyl group at C-7 displayed 5-6 
times lower trypanocidal and leishmanicidal activity than compound 1 with a hydrogen atom at the position (Fig. 1 and Table 1). Likewise, compound 4 is $1.5-4.6$ times less active than compound $\mathbf{3}$ which has a keto functional group instead of a hydroxyl group at the C-7 position (Fig. 1 and Table 1). These findings indicate that a slight increase in hydrophilicity reduces the trypanocidal and leishmanicidal activity of the gedunin-type limonoids.

This study has shown that phytochemical investigation of plants utilised in traditional medicine can yield the identification of compounds apparently responsible for the activity ascribed to their indigenous use. Here it was revealed that six limonoids isolated form the roots of $P$. kotschyi, a plant used for treating trypanosomiasis in domestic animals in Nigeria [6], display anti-trypanosomal activity. Kotschyienone A (1) was found to be not only the most active compound against $T$. brucei but also against $L$. major. Whereas compound 1 did not fully match the $\mathrm{GI}_{50}$ activity criteria for drug candidates for African trypanosomiasis $[<0.2 \mu \mathrm{g} /$ $\mathrm{mL}$ vs $1.09 \mu \mathrm{g} / \mathrm{mL}(2.48 \mu \mathrm{M})$ ], it fulfilled the $\mathrm{GI}_{50}$ activity criteria for drug candidates for leishmaniasis $[<1 \mu \mathrm{g} / \mathrm{mL}$ vs $0.66 \mu \mathrm{g} / \mathrm{mL}(1.51 \mu \mathrm{M})$ ] [22]. The moderate selectivity indices of compound $\mathbf{1}$ did not correspond with selectivity index activity criteria for both parasite species (Trypanosoma $>100$; Leishmania $>20$ [22]). However, it should be pointed out that in this study a cancer cell line was used for determining selectivity and that, compared with non-malignant cells, the cytotoxicity of compound $\mathbf{1}$ may, therefore, be overestimated. For example, the cytotoxicity of $\mathbf{1}$ for the immortalised human embryonic kidney cell line HEK239T was previously determined to be $>200 \mu \mathrm{g} / \mathrm{mL}$ [8]. Based on this cytotoxicity, compound $\mathbf{1}$ would match the selectivity index activity criteria for drug candidates for both bloodstream forms of $T$. brucei and intracellular amastigotes of L. major. In conclusion, the gedunin-type limonoids seem to be a promising class of compounds for further anti-trypanosomal and anti-leishmanial drug development.

\footnotetext{
Acknowledgements The authors are grateful to the Institute of Medical Research and Medicinal Plant Studies (IMPM) of Cameroon for their laboratory facilities; and to the University of Yaoundé I; the Aix-Marseille University; and the University of East Anglia for their research facilities and the award of a UEA Vice Chancellor Global Challenges Research Fellowship.
}

Open Access This article is licensed under a Creative Commons Attribution 4.0 International License, which permits use, sharing, adaptation, distribution and reproduction in any medium or format, as long as you give appropriate credit to the original author(s) and the source, provide a link to the Creative Commons licence, and indicate if changes were made. The images or other third party material in this article are included in the article's Creative Commons licence, unless indicated otherwise in a credit line to the material. If material is not included in the article's Creative Commons licence and your intended use is not permitted by statutory regulation or exceeds the permitted use, you will need to obtain permission directly from the copyright holder. To view a copy of this licence, visit http://creativecommons.org/licenses/by/4.0/.

\section{References}

1. Steverding D (2008) The history of African trypanosomiasis. Parasit Vectors 1:3

2. Steverding D (2014) The history of chagas disease. Parasit Vectors 7:317

3. Steverding D (2017) The history of leishmaniasis. Parasit Vectors $10: 82$

4. Cragg GM, Newman DJ (2013) Natural products: a continuing source of novel drug leads. Biochim Biophys Acta 1830:3670-3695

5. Cheuka PM, Mayoka G, Mutai P, Chibale K (2016) The role of natural products in drug discovery and development against neglected tropical diseases. Molecules 22:58

6. Atawodi SE, Ameh DA, Ibrahim S, Andrew JN, Nzelibe HC, Onyike EO, Anigo KM, Abu EA, James DB, Njoku GC, Sallau AB (2002) Indigenous knowledge system for treatment of trypanosomiasis in Kaduna state of Nigeria. J Ethnopharmacol 79:279-282

7. Ahua KM, Ioset J-R, Ioset KN, Diallo D, Mauël J, Hosettmann K (2007) Antileishmanial activities associated with plants used in the Malian traditional medicine. J Ethnopharmacol 110:99-104

8. Sidjui LS, Nganso YOD, Toghueo RMK, Wakeu BNK, Dameue JT, Mkounga P, Adhikari A, Lateef M, Folefoc GN, Ali MS (2018) Kotschyienones A and B, new antiplasmodial and cytotoxicity of limonoids from the roots of Pseudocedrela kotschyi (Schweinf.) Harms. Z Naturforsch C J Biosci 73:153-160

9. Ambrozin ARP, Leite AC, Bueno FC, Vieira PC, Fernandes JB, Bueno OC, das G. Fernandes da Silva MF, Pagnocca FC, Hebling MJA, Bacci Jr M (2006) Limonoids from andiroba oil and Cedrela fissilis and their insecticidal activity. J Brz Chem Soc 17:542-547

10. Ravangpai W, Theerawattananond T, Pengpreecha S, Muangsin N, Pudhom K (2010) 7-Deacetyl-gedunin. Acta Crystallogr Sect E Struct Rep Online 67:o158-o159

11. Taylor DAH (1974) ${ }^{13} \mathrm{C}$ nuclear magnetic resonance spectra of some limonoids, Part I. The structure of procerin, an extractive from $\mathrm{Car}$ apa procea. J Chem Soc Perkin Trans 1:437-441

12. Cheng Y-B, Chien Y-T, Lee J-C, Tseng C-K, Wang H-C, Lo I-W, Wu Y-H, Wang S-Y, Wu Y-C, Chang F-R (2014) Limonoids from the seeds of Swietenia macrophylla with inhibitory activity against dengue virus 2. J Nat Prod 77:2367-2374

13. Hirumi H, Hirumi K, Doyle JJ, Cross GAM (1980) In vitro cloning of animal-infective bloodstream forms of Trypanosoma brucei. Parasitology 80:371-382

14. Collins SJ, Gallo RC, Gallagher RE (1977) Continuous growth and differentiation of human myeloid leukaemic cells in suspension culture. Nature 270:347-349

15. Baltz T, Baltz D, Giroud C, Crockett L (1985) Cultivation in a semidefined medium of animal infective forms of Trypanosoma brucei, T. equiperdum, T. evansi, T. rhodesiense and T. gambiense. EMBO J 4:1273-1277

16. Ivens AC, Blackwell JM (1996) Unravelling the Leishmania genome. Curr Opin Genet Dev 6:794-710

17. Merschjohann K, Sporer F, Steverding D, Wink M (2001) In vitro effect of alkaloids on bloodstream forms of Trypanosoma bruce $i$ and T. congolense. Planta Med 67:623-627

18. Mikus J, Steverding D (2000) A simple colorimetric method to screen drug cytotoxicity against Leishmania using the dye Alamar Blue ${ }^{\circledR}$. Parasitol Int 48:265-269

19. Huber W, Koella JC (1993) A comparison of three methods of estimating $\mathrm{EC}_{50}$ in studies of drug resistance of malaria parasites. Acta Trop 55:257-261

20. Ferreira ÉR, Horjales E, Bonfim-Melo A, Cortez C, da Silva CV, De Groote M, Sobreira TJP, Cruz MC, Lima FM, Cordero EM, 
Yoshida N, da Silveira JF, Mortara RA, Bahia D (2016) Unique behaviour of Trypanosoma cruzi mevalonate kinase: a conserved glycosomal enzyme involved in host cell invasion and signalling. Sci Rep 6:26410

21. Hay A-E, Ioset J-P, Ahua KM, Diallo D, Brun R, Hostettmann K (2007) Limonoid orthoacetates and antiprotozoal compounds from the roots of Pseudocedrela kotschyi. J Nat Prod 70:9-13

22. Nwaka S, Hudson A (2006) Innovative lead discovery strategies for tropical diseases. Nat Rev Drug Discov 5:941-955
Publisher's Note Springer Nature remains neutral with regard to jurisdictional claims in published maps and institutional affiliations. 